\title{
Wind Energy in the Mediterranean Spanish ARC: The Application of Gravity Based Solutions
}

\author{
Javier Abanades* \\ TYPSA, Edificio Manuel Borso, Valencia, Spain
}

Almost $90 \%$ of the world's marine renewable energy is generated in Europe, however the contribution of the Mediterranean Sea in the energy mix is practically negligible. On this sense, the present article presents the advantages of implementing a Blue Energy Project (offshore wind farm) in the Mediterranean Spanish Arc using certain type of technology: Gravi3 ${ }^{\circledR}$, a gravity based solution for the foundation of Wind Turbine Generators (WTGs). The analysis of the renewable energy potential and the boundary conditions of the case study analyzed (Cadiz) vindicates that the viability from both the technical and economic point of view can be assured.

Keywords: marine renewable energy, offshore wind energy, Mediterranean Sea, gravity based solutions, hybrid structure, self-buoyant structure, self-installing structure

OPEN ACCESS

Edited by:

Simone Bastianoni,

University of Siena, Italy

Reviewed by:

Nicoletta Patrizi,

University of Siena, Italy

Carlos Perez-Collazo,

University of Vigo, Spain

*Correspondence:

Javier Abanades

jabanades@typsa.es

Specialty section:

This article was submitted to

Energy Systems and Policy,

a section of the journal

Frontiers in Energy Research

Received: 31 July 2018

Accepted: 31 July 2019

Published: 24 September 2019

Citation:

Abanades J (2019) Wind Energy in the Mediterranean Spanish ARC: The

Application of Gravity Based

Solutions. Front. Energy Res. 7:83.

doi: 10.3389/fenrg.2019.00083

\section{INTRODUCTION}

The necessity of fostering renewable energies lies in the well-known adverse effects brought about by the world's reliance on fossil fuels: (i) greenhouse gas emissions that exacerbate climate change, (ii) diminished reserves of carbon fuels, and (iii) geopolitical wrangling over the control of the oil and gas reserves, which has led to many conflicts and all-out wars in the last decades. In addition, the variability in oil and gas prices has a deleterious effect on the global economy. These arguments, and the international treaties and protocols signed to foster the efforts against climate change, call for the development of renewable energy sources.

Among renewable energies, the potential of the different sources of Marine Renewable Energy (MRE) is widely recognized (Drew et al., 2009; Bahaj, 2011; Astariz and Iglesias, 2015), so much so that it is poised to become a fundamental pillar in the EU energy policy, cf. the European Strategic Energy Technology Plan (SET-Plan) described in European Commission (2007). In fact, the MRE industry has established for ocean energy (wave and tidal) and offshore wind a target of installed capacity for 2050 of 188 and 460 GW, respectively (Association, 2010; Jeffrey and Sedgwick, 2011; Moccia et al., 2011), which are ambitious goals given that the figures for 2020 are 3.6 and $40 \mathrm{GW}$ (EWEA, 2012).

It can be readily observed that to meet these objectives, the development in the Mediterranean Sea must be fostered (Abanades and Torregrosa, 2018). This is reflected in the wind energy figures, a resource more mature than the rest: by the end of 2016 with a total of $18 \mathrm{GW}$ installed in Europe, 3 GW were installed in the Irish Sea, 2 GW in the Baltic Sea, and 13 GW in the North Sea (Wind Europe, 2017). Although, there were obvious singularities that limited the development of wind energy in the Mediterranean Sea in the past, with the current technology and knowledge acquired, these shortcomings are being overcome and wind energy will become a reality in the near future. Similarly, this can be applied to other renewable energy resources. 


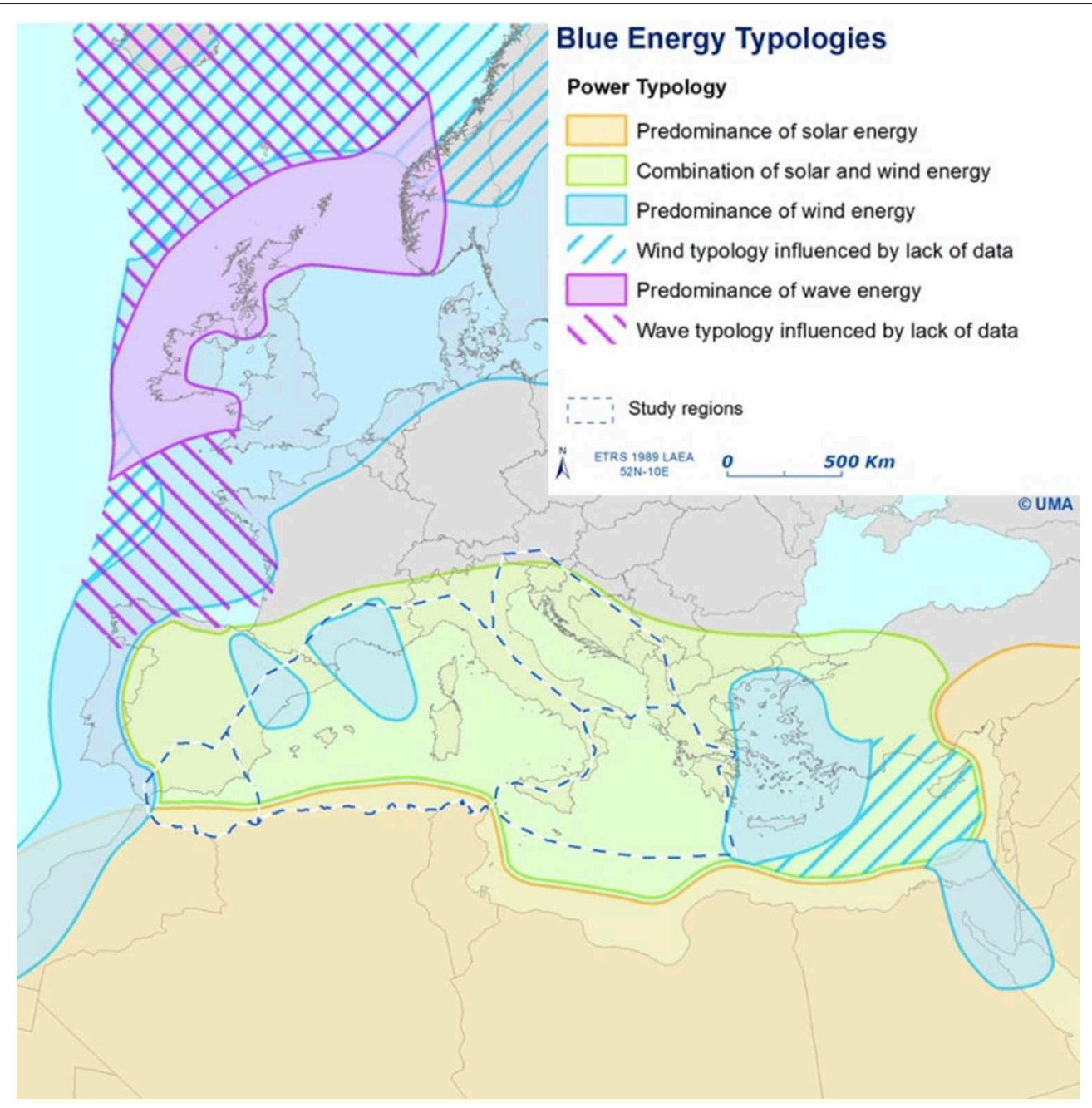

FIGURE 1 | Blue Energy Typologies in Europe. Reproduced from ASME (Abanades et al., 2018a) based on information of Aqua-RET project.

The interest of the Mediterranean Sea is reflected by the large number of studies evaluating its abundant and diverse natural resources. Wind energy has been evaluated from different scales: from the transnational one (Lavagnini et al., 2006; Menendez et al., 2014; Zountouridou et al., 2015) to the national one (Sahin et al., 2005; Shata and Hanitsch, 2006; Westerberg et al., 2013). Similarly, the wave energy resource has been also deeply analyzed by different authors (Arena et al., 2013; Liberti et al., 2013; Vicinanza et al., 2013; Sierra et al., 2014; Besio et al., 2016; De León et al., 2016).

These studies vindicate that the resource in the Mediterranean Sea can be very valuable in certain areas, as shown in Figure $\mathbf{1}$. It cannot be overlooked the potential synergies associated to

Abbreviations: MRE, Marine Renewable Energy; EU, European Union; MED Area, Mediterranean Area; GBS, Gravity Based Solution; GBF, Gravity Based Foundation; TLP, Tension Leg Platform; HLV, Heavy Lift Vessel; GBF, Gravity Based Foundation; WTG, Wind Turbine Generator; OWTG, Offshore Wind Turbine Generator; ULS, Ultimate Limit State; RAO, Response Amplitude Operator; NM, Nautical Miles. harness marine renewable energy resources, since this type of project can bring about positive impacts, not only from the economic point of view, but also from the environmental one. For example, it has been proven that the development of wave energy can lead to the reduction of erosion in the beaches behind the wave farm (Abanades et al., 2014, 2018a; Mendoza et al., 2014; Bergillos et al., 2018). This is a clear example of development that will act on the root of the climate change (reduction of $\mathrm{CO}_{2}$ emissions and increase the renewable energy share in the energetic mix) and on the consequences (increase of erosion on the beaches). Other advantages that could generate the development of offshore platforms are the dual application for the harnessing different renewable resources (Stoutenburg et al., 2010; Astariz et al., 2015a,b; Abanades et al., 2018b) and/or the combined application with aquaculture farms (Firestone et al., 2004; Buck et al., 2010).

However, although to meet the objectives of energy mix it is of particular relevance the utilization of the valuable sources provided by the Mediterranean Sea, this is a great 


\section{Looking further offshore and in deeper waters}

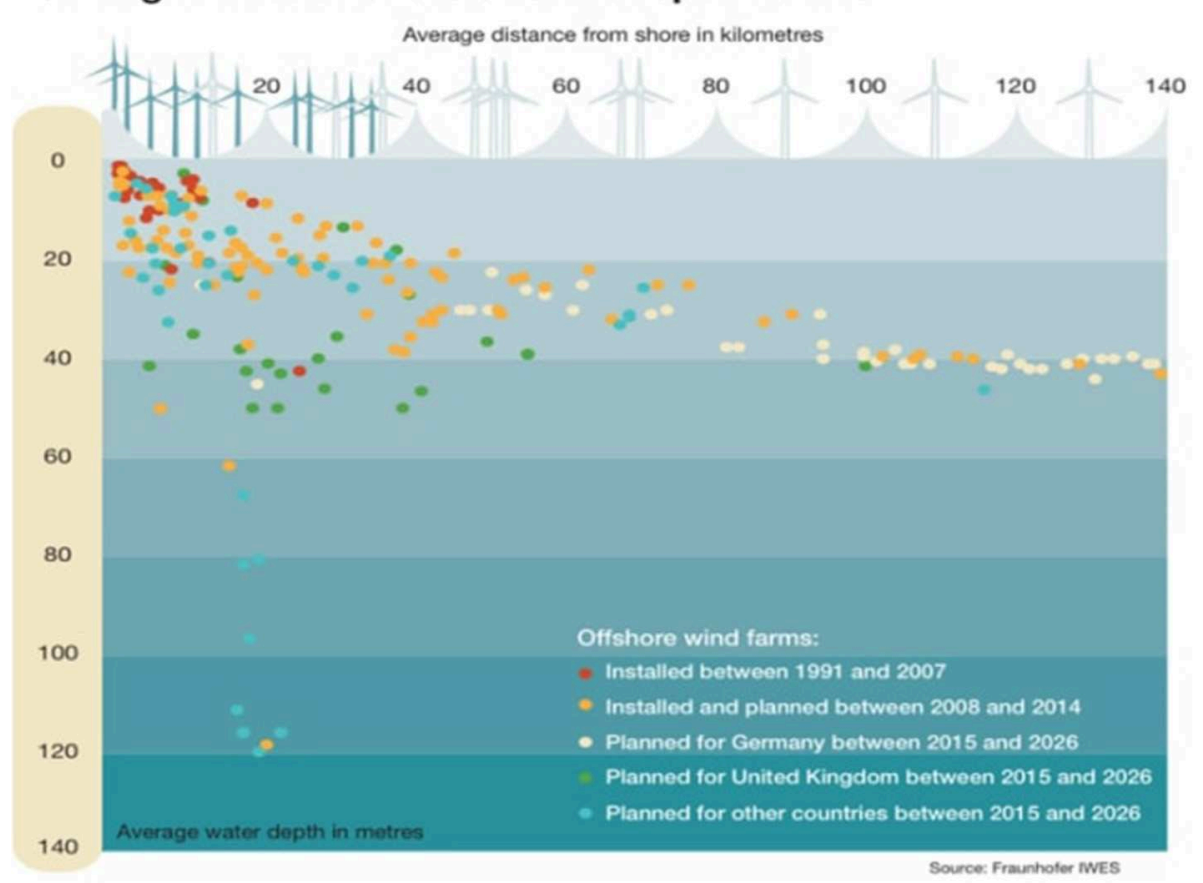

FIGURE 2 | WTG Foundation vs. water depth. Reproduced from Fraunhofer IWES and obtained in the following link of Grid-Arendal: http://old.grida.no/graphicslib/ OpenFile. aspx?id=09ffa8b4-86ca-4d5e-983f-42269b279226.

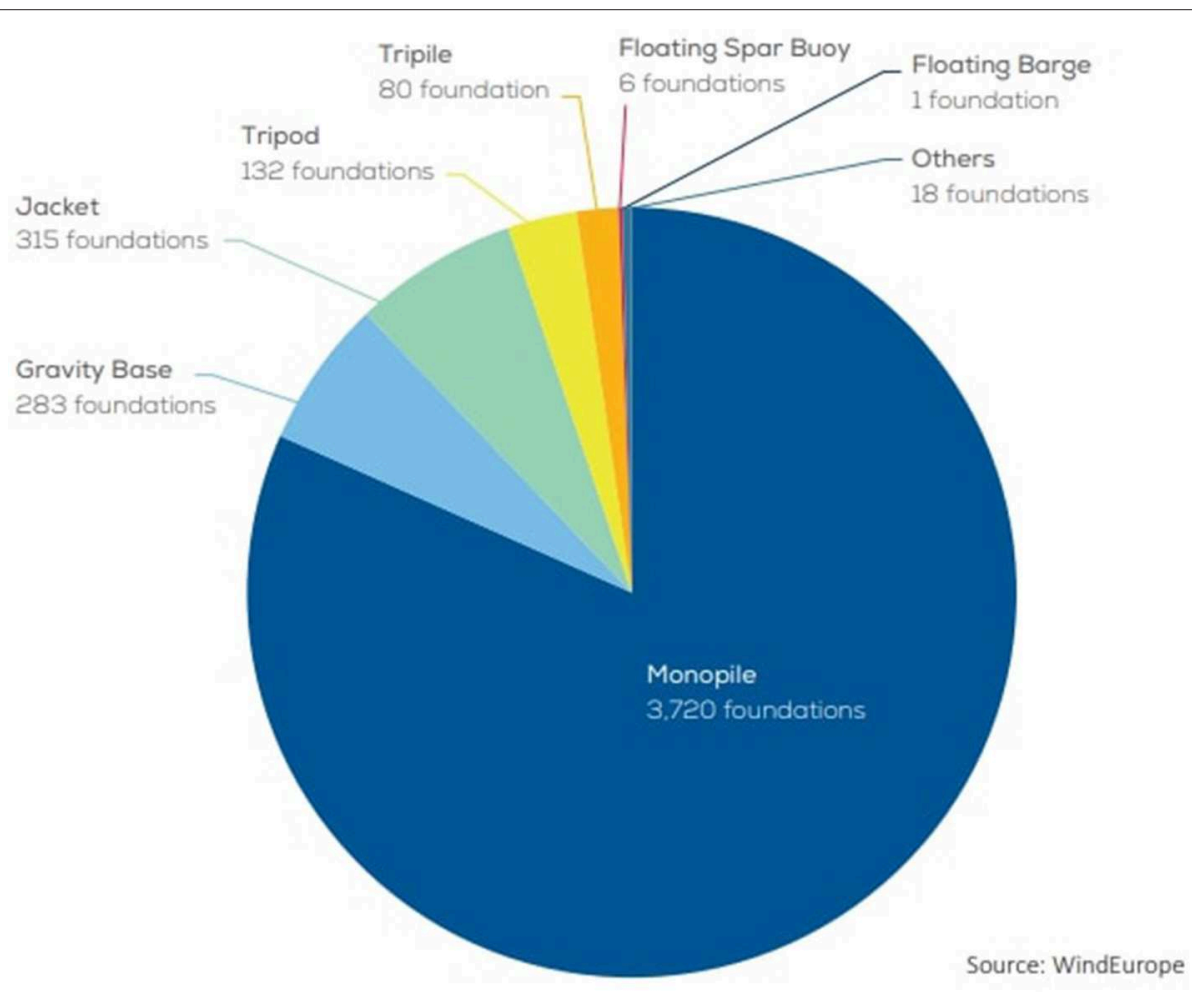

FIGURE 3 | Number of foundations according to its type. Reproduced from WindEurope. 


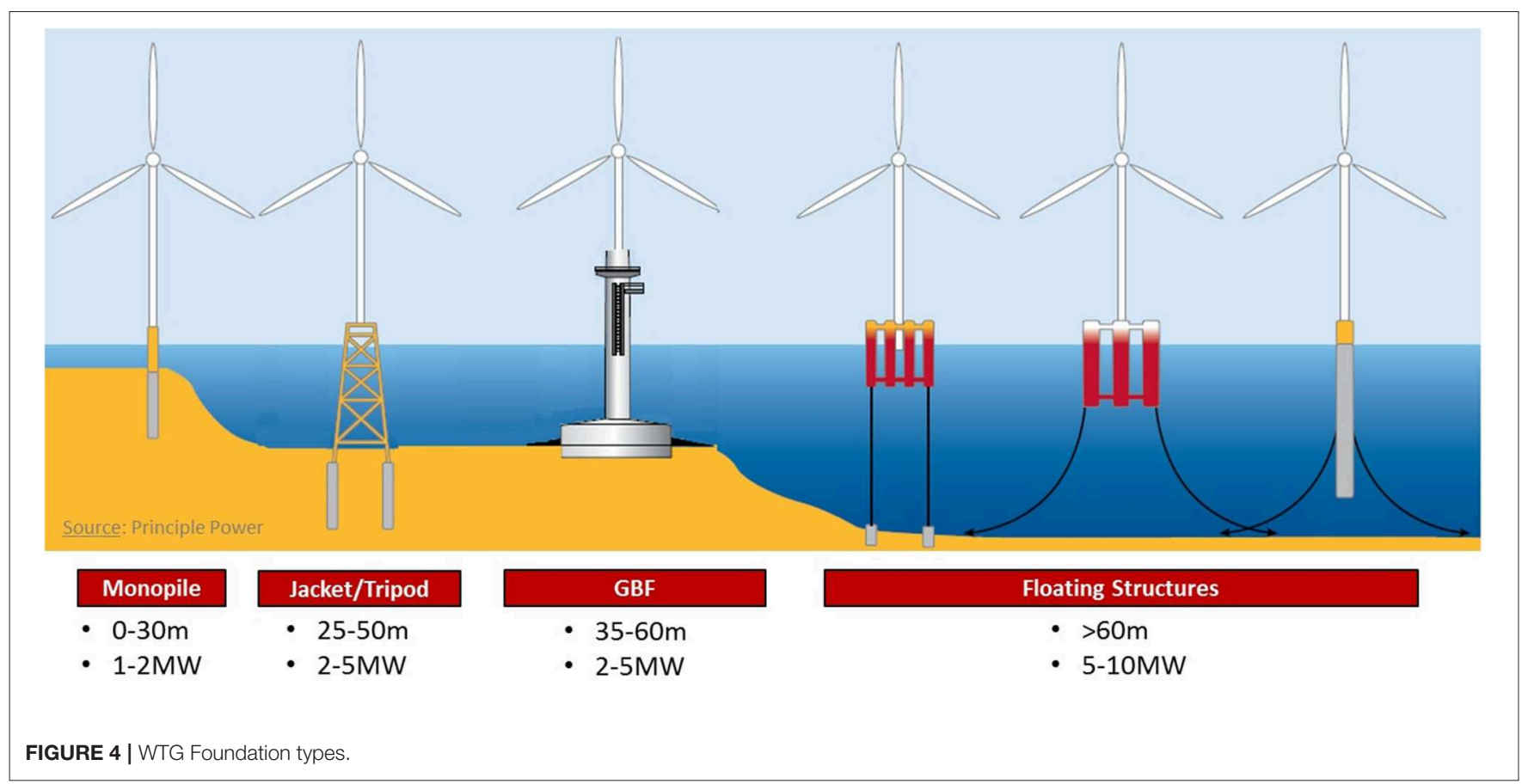

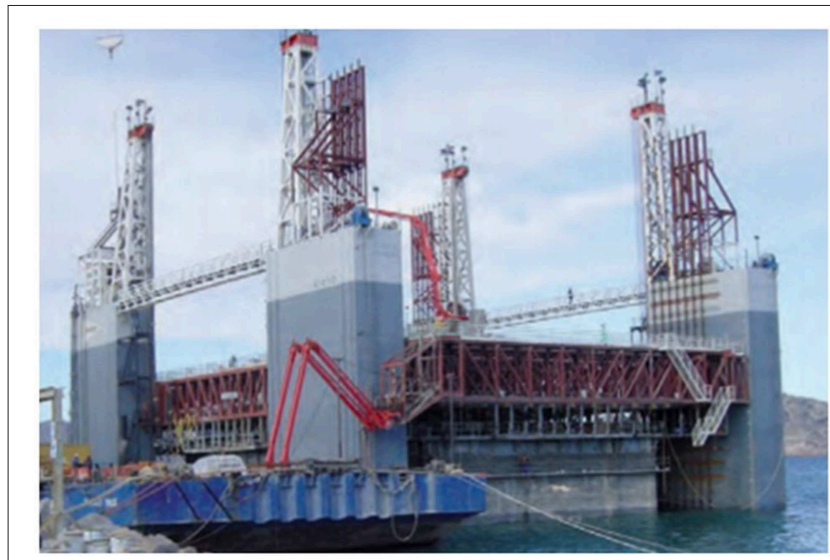

FIGURE 5 | Floating dock.

challenge as blue growth has to be carefully planned due to the singularities of this area compared to others. A wider range of variables and constraints must be taken into account, such as legal aspects, environmental and landscape issues and potential affection on the tourism or other activities as fisheries.

It must be noticed that the MED area comprised the whole Mediterranean Arc plus the South Spanish and Portuguese Coast until Cape Saint Vincent. Actually this area constitutes a prime location for the development of such projects due to its large continental platform. Indeed, several projects have been promoted by different developers for the installation of the first offshore wind farm in Spain, but all finally ended up in their cancellation by several reasons. The complexity of the development of Marine Renewable projects in the Med Area is reflected in the Southwest Coast of Spain (Cadiz), in which a project of 1 GW was planned and was finally rejected by the opposition of the city councils, fishermen's unions and the tourism industry, whereas the regional and national administrations were favorable to its development (Todt et al., 2011). This proves the necessity of engaging the whole society in the decision making process.

The present article aims at evaluating the potential of the Mediterranean Spanish Arc for the development of a wind farm, considering a type of foundation: gravity based. This technology presents a large number of advantages, particularly in Spain, as it can takes advantage of the well-developed technology of the floating docks. The article is structured as follows; the advantages of gravity based solutions are presented through a foundation type: Gravi3 ${ }^{\circledR}$, the area of study of the potential of the Spanish Mediterranean Arc is studied and finally the synergies between the type of foundation and the boundary conditions are analyzed.

\section{STATE OF THE ART}

\section{Wind Turbine Foundations According to the Water Depth}

The main reason that may lead to a slowdown in the growth of offshore wind energy is the depletion of the ideal positions for the installation of wind turbines (depths of $<20 \mathrm{~m}$ ), since the areas with larger continental platforms (e.g., North Sea) are currently close to saturation (Figure 2). For this depth, the monopile technology (use of large diameter individual piles) is optimal both in terms of cost and constructive feasibility. 
In fact, the market is clearly led by the monopile (Figure 3) with a share always higher than $70 \%$ since 2011 (Wind Europe, 2017). However, at greater depths, the monopile does not become the ideal technology and there is a need to develop new solutions that are as competitive as the monopile at lower depths.

In this area, different solutions appear whose technical and economic viability depend on the range of depths (Figure 4). Shallow waters are defined as depths between 5 and $20 \mathrm{~m}$; the intermediate waters for depths between 20 and $60 \mathrm{~m}$; and the deep waters to those $>60 \mathrm{~m}$. Solutions by gravity (known as GBS), tripods and jackets have the highest market share at intermediate depths. For greater depths, the cost of foundations is increased and current market trends are similar to those applied in the oil industry (e.g., Spar, TLPs or floating) (Higgins and Foley, 2013).

\section{Gravity Based Solutions}

One of the types of GBSs is based on caisson-type solutions. Most of GBS have been used in wind farms located in shallow waters $(<20 \mathrm{~m})$, in which the geotechnical conditions of the sea bed make piling unfeasible. In case of shallow waters, the most popular manufacturing process for GBS consists in the construction, in port water, of several units on a barge which is then towed to site by means of tugs. A Heavy Lift Vessel (HLV) is required to lift each unit from the barge and lower it to the final position. This process was employed in the construction of wind farms such as: Nysted commissioned in 2003, Lillgrund in 2007, Sprogø in 2009, Rødsand in 2010, and Kårehamn in 2014

An example of GBS in medium waters is represented by those installed at Thornton Bank, in Belgium's North sea water at a depth of around $30 \mathrm{~m}$. In this case, the six concrete GBSs were constructed on the dock, moved by means of self propelled modular transporters to the end of the dock where they were loaded by an HLV. The HLV transported the structures that could not float, in a partially submerged configuration to allow the buoyance force to partially counteract the gravity load.

All examples above needed HLVs to accomplish the transport and installation processes of GFBs. Since HLV s have very limited availability, they have very high charter rates and the necessity of using them jeopardizes the economic competitiveness of GBSs. For this reason, the most recent designs of GBSs are self-buoyant structures that can be towed afloat using tugs, a type of ship very common in the market.

On this basis, it can be concluded that, when GBSs are compared with other foundation types suitable for intermediate waters $(30-50 \mathrm{~m})$ such as steel tripods and jackets, the possibility of making the former self-buoyant represents a crucial advantage respect to the latter since it offers a way to make their installation independent from the HLVs. Moreover, while the complete installation of a tripod or jacket foundation takes 2-3 days from its arrival at site, the complete installation of a gravity base foundation generally requires $<24 \mathrm{~h}$. This reduction in the installation time has a positive effect on the number of time windows available for the installation of the foundation and, a result, on the final cost of the energy.

\section{Caisson-Type Solutions}

Caissons are concrete prisms whose dimensions can vary as a function of the water depth (its height) and the wave climate (its width and length). They are formed by cellular structures empty inside that allow them to be self-buoyant after their construction. The filling of these cells, either by means of water or granular materials, provides the necessary weight to support the action of the waves. Although, they can be built in dry docks, the most common approach is to the employ of floating docks (Figure 5). This method presents several advantages: (i) for the dimensions of the caissons $(30-40 \mathrm{~m}$ ) the necessary draft of the dry docks would limit the number of feasible ports and therefore the costs would be too high, (ii) the launching of the caissons using dry floating docks simplify this operation, (iii) simultaneous floating dock can operate at the same time, which is very unlikely in the case of dry docks.

On this sense, the employ of floating docks results in very high ratios of production. A typical value assumed for the caisson construction is $3 \mathrm{~m}$ of caisson height per day. As the caissons have

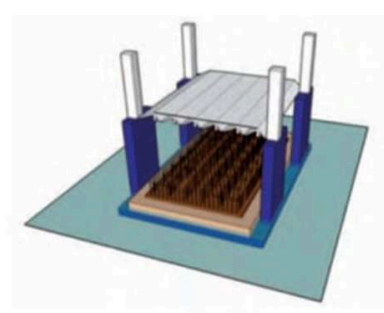

Step 1: The steel cage of the bottom slab of the caisson is provided by means of a pontoon. The floating dock is submerged to allow the entrance of the pontoon.

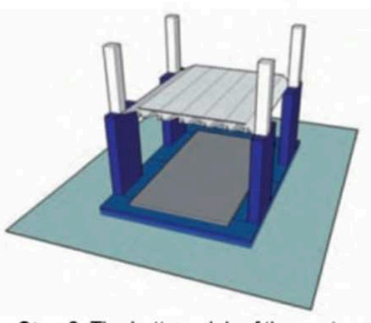

Step 3: The bottom slab of the pontoon is emerged and the steel cage is placed over it

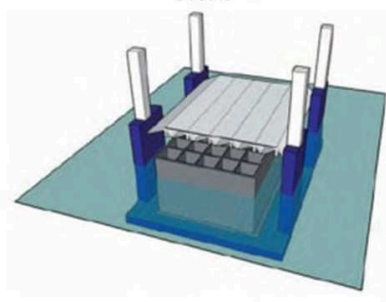

Step 5: The pouring process until the total height of the caisson is reached. The top slab of the caisson is installed once finished

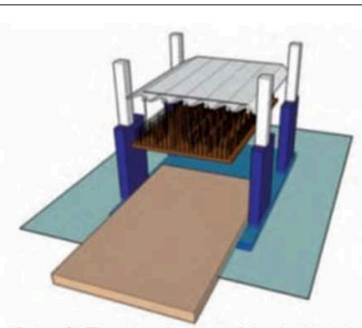

Step 2: The steel cage of the bottom slab is hanged by the floating dock, while the pontoon is removed

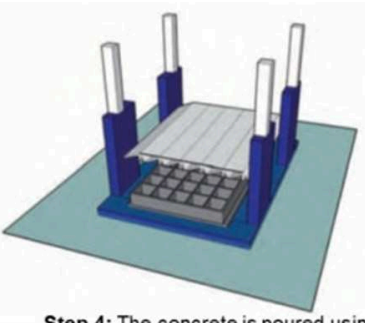

Step 4: The concrete is poured using a formwork and the bottom slab of the floating dock starts to submerge as the caissons starts to rise

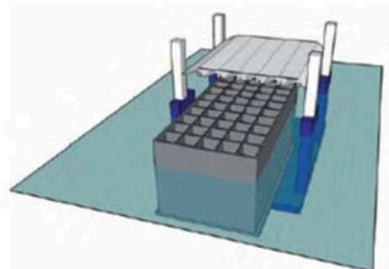

Step 6: The caisson is launched by means of auxiliary maritime resources
FIGURE 6 | The process of building a caisson using a floating dock. Adapted from Puertos del Estado (Puertos del Estado, 2008). 
a total height of approximately $30 \mathrm{~m}$, approximately the duration for building a caisson would be 10 days. In addition to this, the lunching of the caisson and the preparation for the next one is estimated in a couple of days, which makes a total duration of caisson fabrication of 12 days (Figure 6).

Beyond the utilization of caissons in breakwaters, the wellmature technology for the caisson construction has led this type of elements to transcend to other fields, namely the offshore winds, thanks to the savings in the maritime resources for the installation of these elements. TYPSA has been pioneered in the employ of the typical caissons of breakwaters for foundation purposes. The meteorological masts of Moray Firth and Inch Cape (Scotland) were supported by hybrid foundations formed by a concrete caisson and a steel shaft, which ends in a deck structure that connects the foundation with the Meteorological Mast (Figure 7).

The main advantage of this foundation is the limited number of maritime resources to perform the operation. On this basis, TYPSA continued developing the concept of using caissons for supporting structures and this came up a with a ground-breaking foundation solution for Offshore Wind Turbine Generators (OWTGs): Gravi3 ${ }^{\circledR}$.

This concept consists in an innovative hybrid concretesteel, self-buoyant bottom standing gravity based foundation

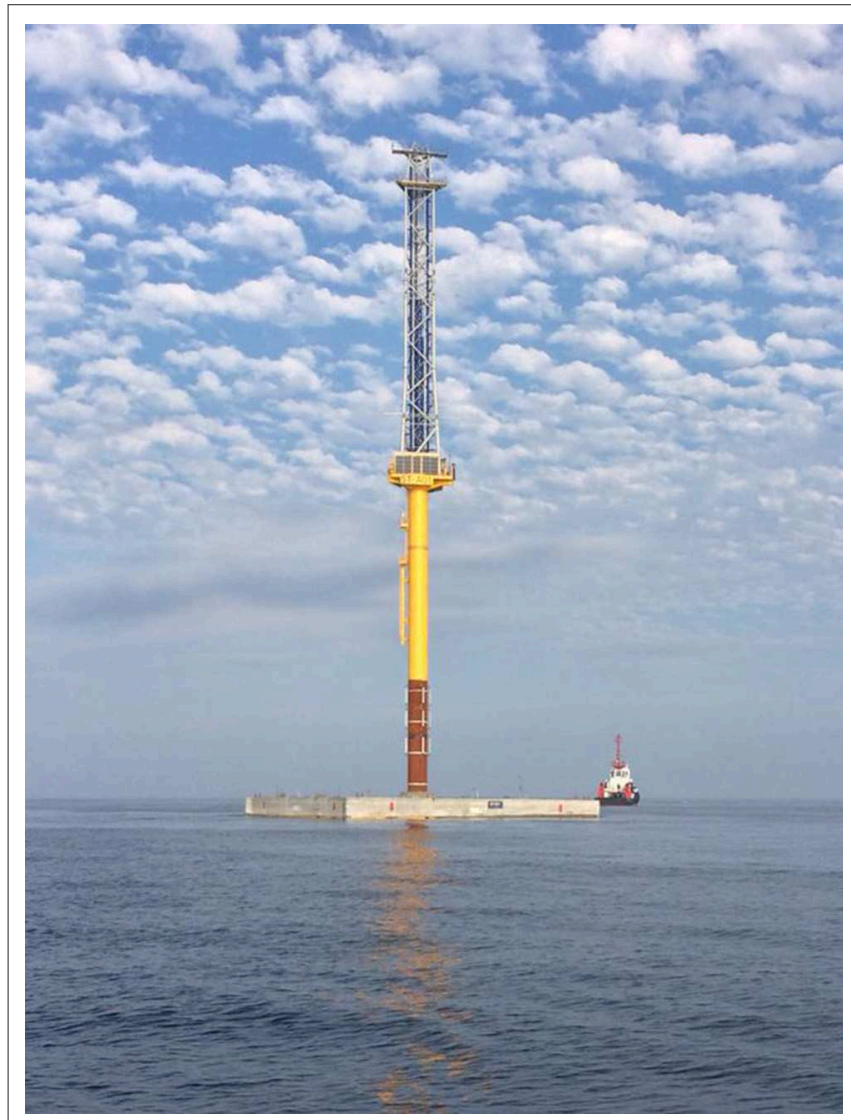

FIGURE 7 | Towing of the Meteorological mast foundation of Moray Firth.
(GBF) for offshore wind farms positioned in water depths between 35 and $60 \mathrm{~m}$. The foundation lies in 3 concrete caissons that are connected through a steel tripod. The complete unit (turbine and foundation) will be built and assembled onshore and towed while floating to the deployment site, where it will be submerged by an innovative patented process on a controlled way without the need for external support or heavy lift vessels.

\section{GRAVI3 ${ }^{\circledR}:$ A New GBS Concept}

All the GBFs concepts presented in the previous section present one or more of the following restrictions: necessity of a yard at the base port for their construction onshore, slow construction rates due to the use of standard climbing formworks, necessity of using solid ballast to obtain the required self-weight for geotechnical verifications at the Ultimate Limit States (ULSs), and impossibility to transport the wind turbine fully assembled.

The GRAVI3 ${ }^{\circledR}$ foundation has been designed to overcome all these restrictions. It is a self-buoyant GBF formed by 3 reinforced concrete caissons which support a steel tripod (Figure 8). The key aspect of this design is that it does not require the use of HLVs and jack-ups in any phase of the project implementation. The reinforced concrete caissons are built on a floating dock using sliding formworks not requiring onshore construction yards and maximizing the construction rate.

The combination of the tripod and reinforced concrete caisson typologies permits exploiting simultaneously the permeability of the tripod, which greatly reduces the wave induced loads on the structure, and the high dead load of the caissons, which avoid the need for piling into the seabed, thus eliminating the issues related

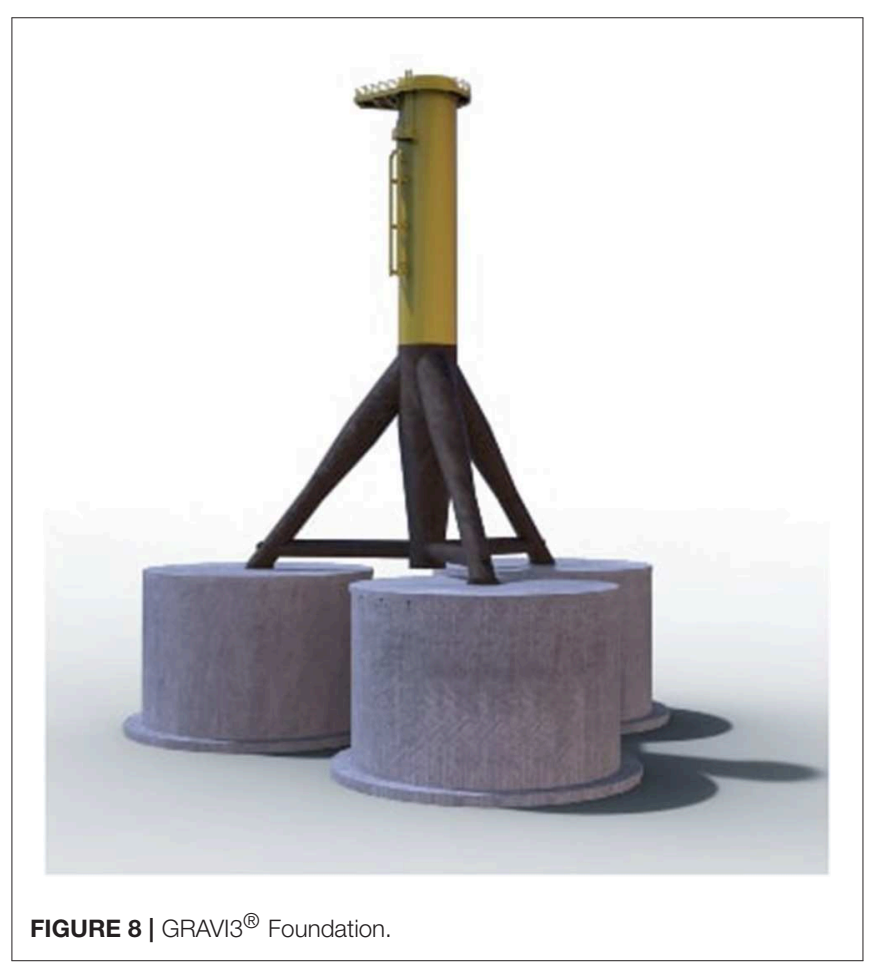


with the noise generated by piling and making the foundation well-suited for hard and rocky sea bed. For softer materials, sea bed preparation shall be conducted.

This three leg concept provides naval stability to the whole structure allowing its transport fully assembled (WTG included). In service conditions (as bottom fixed foundation), the three caissons improve the behavior of the structure against overturning and minimizes the stresses transmitted to the foundation soil. GRAVI3 ${ }^{\circledR}$ can be installed by means of filling the caisson cells with water, and no solid ballast is required to provide additional weight. This feature of the design simplifies the decommissioning operations of the structure since it can be re-floated pumping out water from the caissons.

Other advantages that this solution presents are, among others: (i) the minimization of the use of port area for construction and storage (see supply chain of the solution in Figure 9), (ii) the possibility of installation at any period of the year (as the operation does not last long, a weather window of $24 \mathrm{~h}$ is sufficient to conduct such operation), and (iii) the possibility of decommissioning as the pumps installed for the installation can serve for the re-floating process.

One of the most challenging aspects of the design of this structure was the assessment of the hydrodynamic loading.

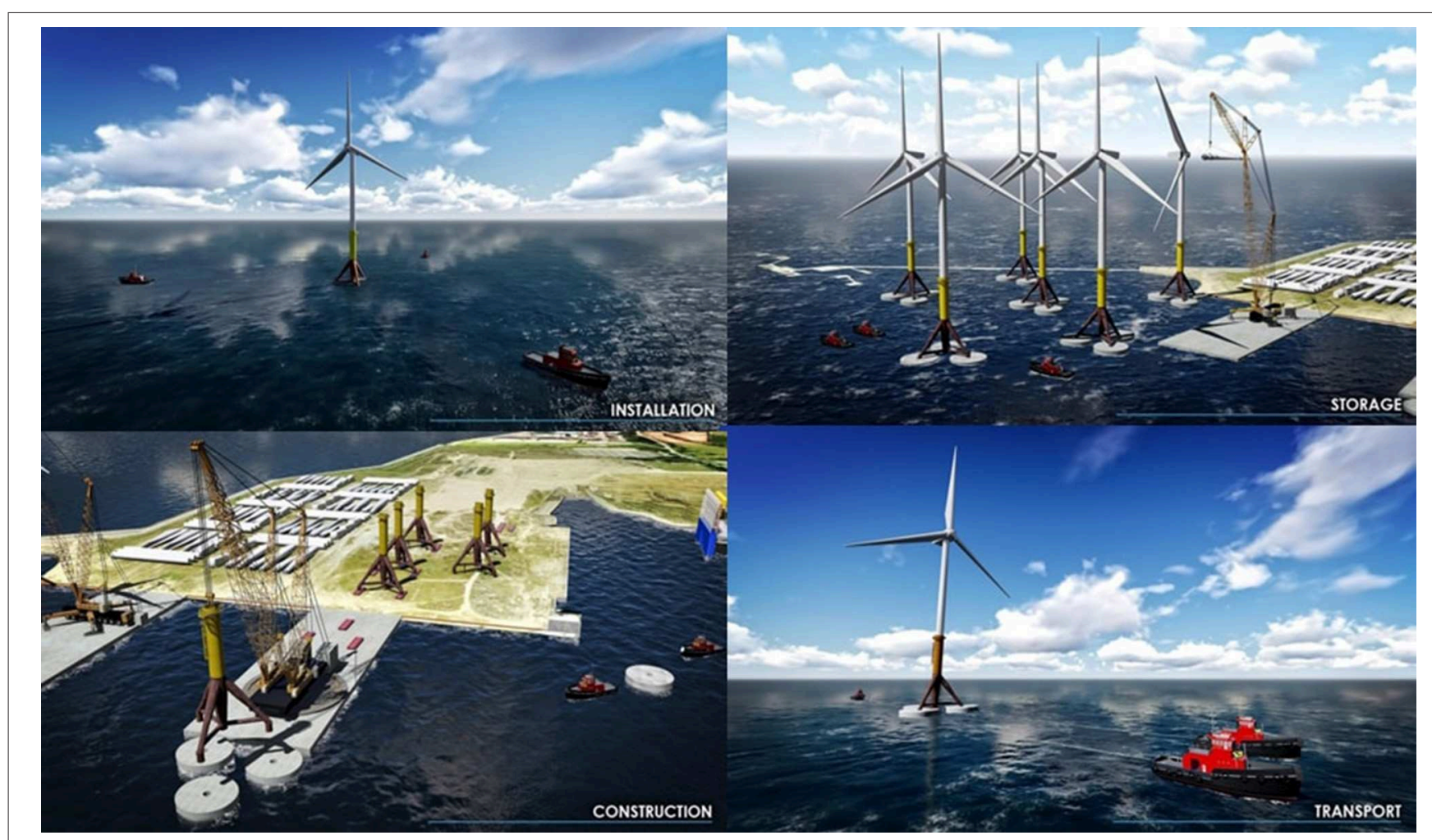

FIGURE 9 | GRAVI3 ${ }^{\circledR}$ Supply Chain.

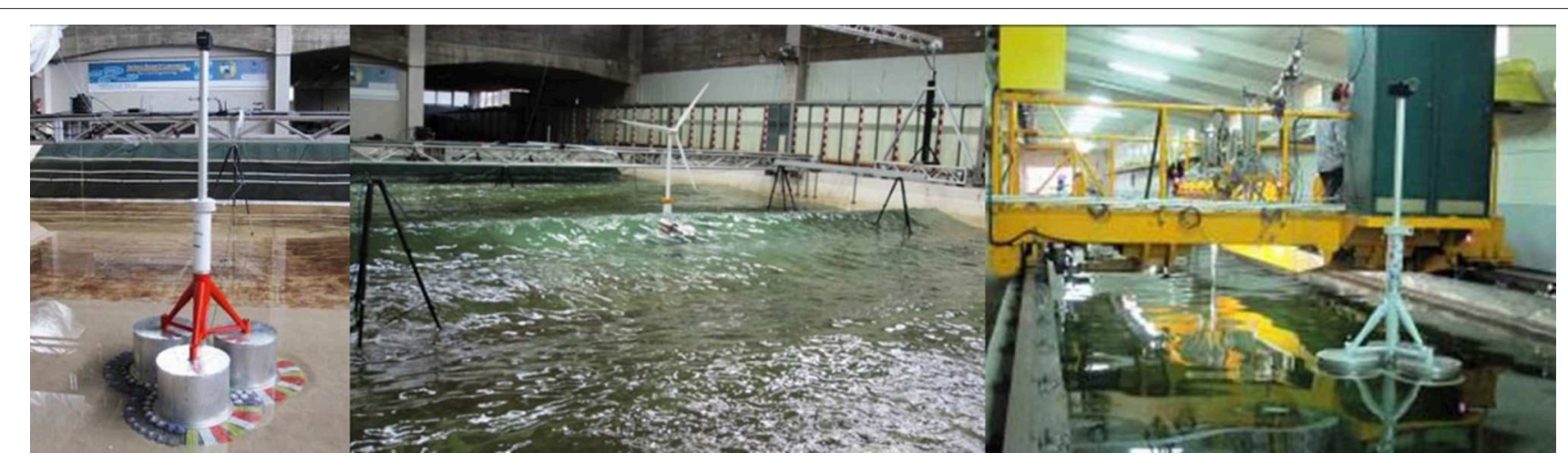

FIGURE 10 | GRAVI3 ${ }^{\circledR}$ Physical campaign conducted at HRL-UPM and CEHINAV. 
The structure is comprised of three caissons (elements of great dimensions), whose movements during the transport were driving the loads of the tripod (slender elements). Whilst the waves pass through the slender element, their patters are not altered; the caissons modified completely the wave behavior. Then different wave theories were used: Morison equation for the slender elements and diffraction theory for the caissons.

Furthermore, the methodology considered varied significantly as a function of the scenario studied: floating (transport and installation) or fixed (service life). For calibrating the different numerical models, physical campaigns (for the different phases of the project: towing, installation and bottom fixed) were conducted at a scale of 1:50 in the most cutting-edge facilities of Europe (Figure 10).

In the case of the towing, the calibration of the numerical model was carried out by means of additional Morison elements

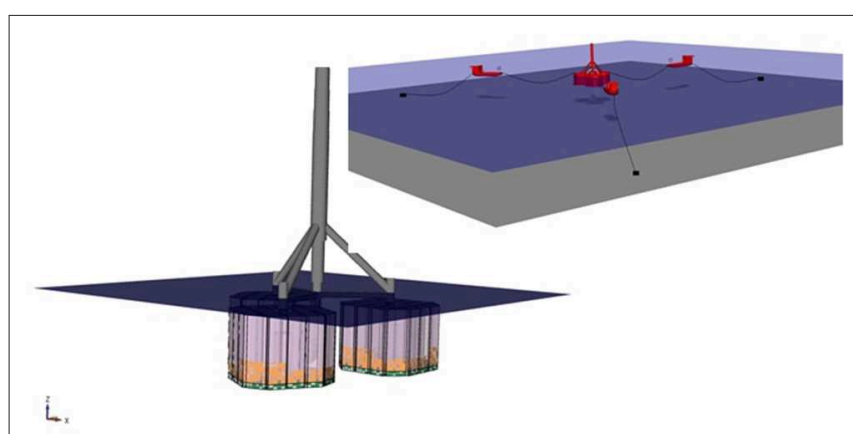

FIGURE 11 | Installation configuration and ballasting process. integrated on the caissons in order to simulate non-linear effects, particularly the viscous damping. For this purpose, the Response Amplitude Operators (RAOs) obtained in the physical campaign were established as the target of the numerical model output. Once calibrated the structure response, the wave loading was compared between the physical and numerical model, achieving a successful correlation between both models. Same accurate results were found with the fixed model during the service life and for the installation process.

Finally, regarding the installation a similar procedure than the one applied to the met masts installed in the North Sea (Figure 7) is employed. Three tugs are used to allow the corrections of the position and orientation. Finally, an automated system is developed for filling the groups of cells of the caissons with the objective of conducting a controlled descend of the structure. Then, the ballast process is used to correct any adverse trend that can occur during the process (Figure 11).

As can be seen, one of the main advantages of the solutions is its validity to a wide range of locations, as the solution can be used in a wide range of water depth, with different type of soils and at different coast-to-farm distances. On that sense, the following section will analyze its validity in the Spanish Coast.

\section{CASE STUDY: POTENTIAL ANALYSIS IN CADIZ}

The present section includes the analysis of the potential of an area for the implementation of a Marine Renewable Energy Project, in this case, more specifically about the development of an offshore wind

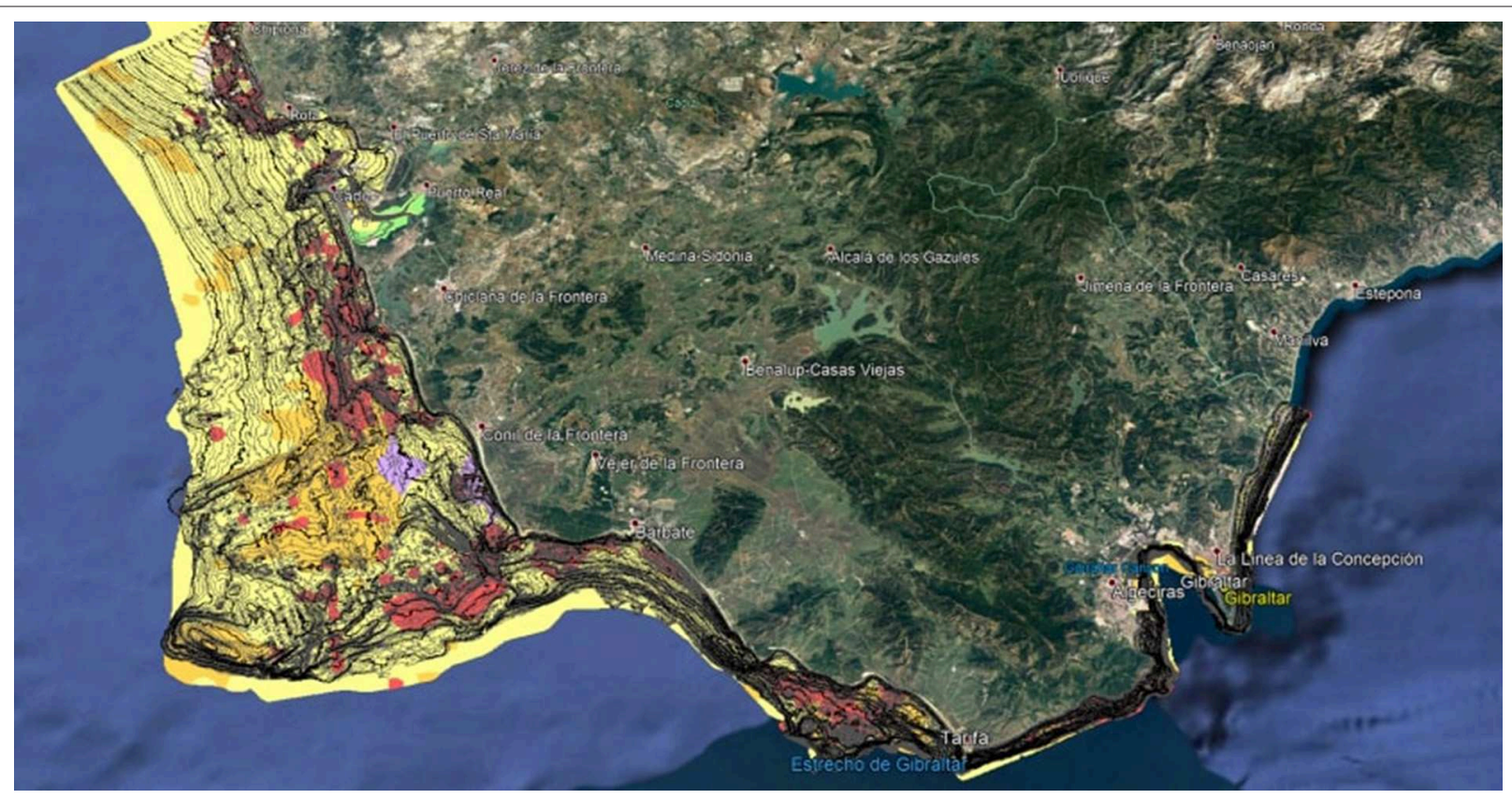

FIGURE 12 | Bathymetry and marine geomorphology along the Cadiz Coast (Spain). Map data: Google, DigitalGlobe; Data reproduced from Ecocartografias - Ecological transition Spanish Minister. 


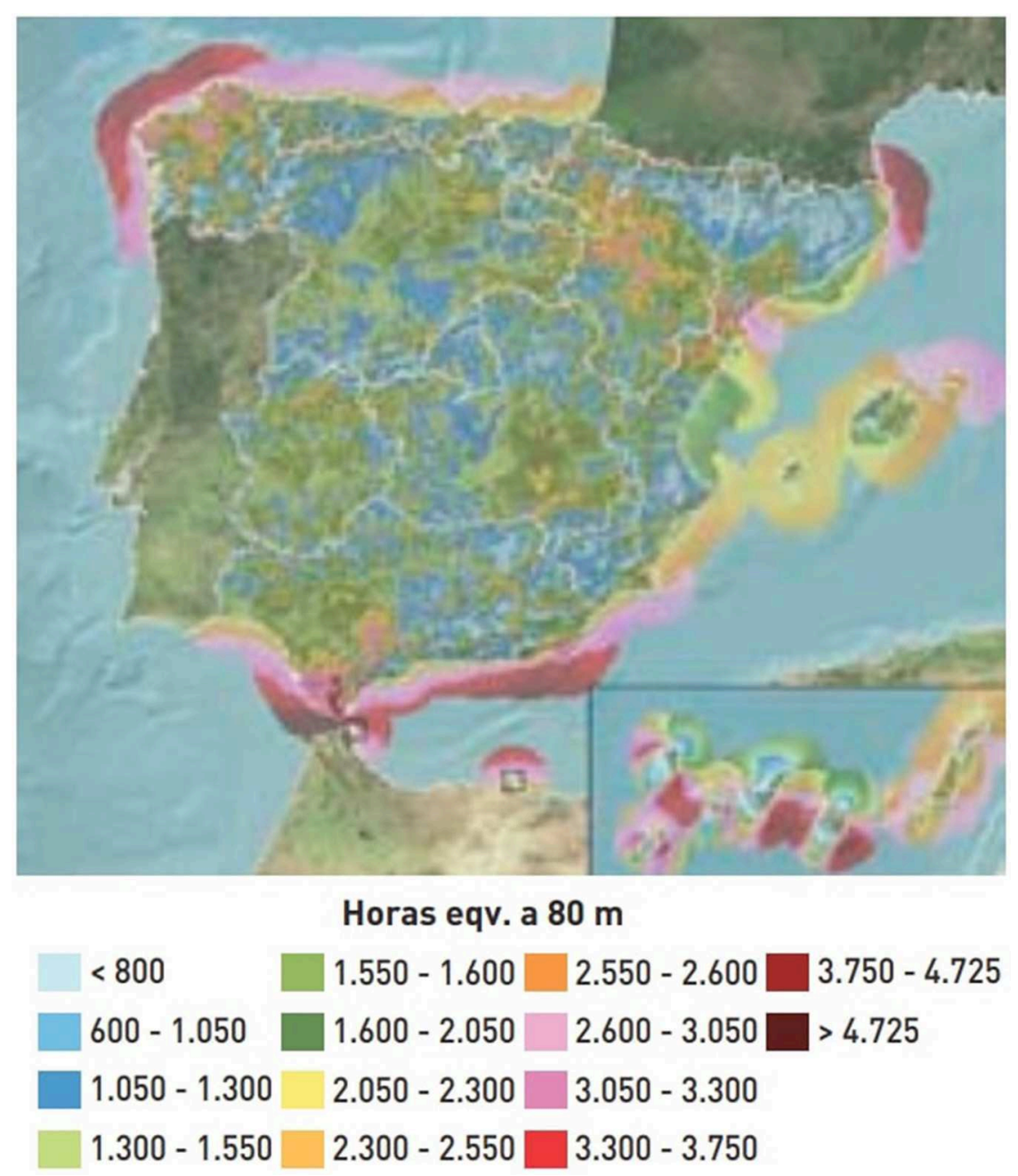

FIGURE 13 | Number of equivalent hours with full performance per year. Reproduced from IDEA.

farm. The case study selected is the West Coast of Cadiz (Spain).

One of the main shortcomings of the Mediterranean Area is the water depth, due to the absence of continental shell. In this sense, the first analysis for assessing the viability of a bottom-fixed foundation must be related to the bathymetrical and marine geomorphology analysis along the coast of Cadiz (South Spain).

Figure 12 depicts the area of interest for the installation of offshore wind, as it presents a shallow platform, with water depths lower than $50 \mathrm{~m}$ at a distance of 16 Nautical Miles (NM) from the Coast, which practically reduces completely any visual impact that could bring about an offshore wind project and therefore any impact in the tourism industry. Furthermore, the materials in the area are competent sands (yellow and orange materials) with the presence of rock (red) which are very competent for the installation of gravity based structures (enhancing like that one of the main capabilities of the area, which is the construction of concrete caissons). Actually, the presence of rock could limit the applicability of piled solutions (as jackets or monopiles).
It can be readily observed the differences between the East and West Coast of Cadiz. While, the platform in the west coast is very shallow ( $50 \mathrm{~m}$ water depth between 10 and 16 nautical miles), the east coast is very scarp with water depths $>50 \mathrm{~m}$ in $<2$ nautical miles.

The interest of the area is corroborated with the wind resource analysis (Figure 13). This shows that in the case of Cadiz (nearby Gibraltar Strait), and other hot spots in Spain, the number of equivalent hours at $80 \mathrm{~m}$ height can reach near the $4,000 \mathrm{~h}$ per year, which is a similar value to the resource found in the North Sea. With this resource, and the current degree of development for the WTG, the economic viability of such a project is fully guaranteed.

Finally, to determine the potential of the area is necessary to evaluate the viability of the project according to the regulations and the protected areas. Figure $\mathbf{1 4}$ shows that although there are several protected areas, mainly localized around the Gibraltar Strait, the area of the case study is not included in any special protected figure. 


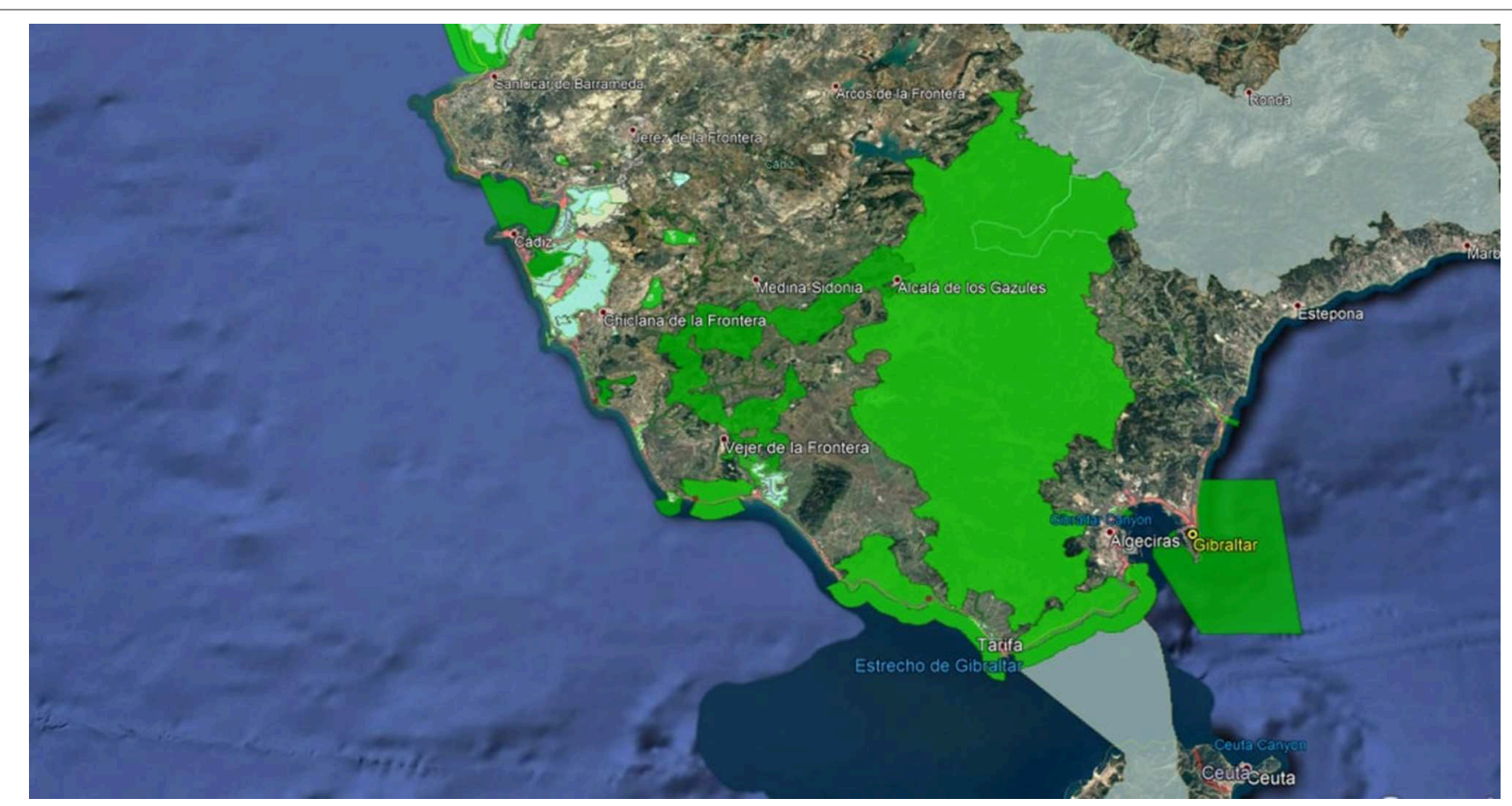

FIGURE 14 | Land cover along the coast and natural protected areas along the Coast of Cadiz (Spain). Map data: Google, DigitalGlobe. Information reproduced from Ecocartografias-Ecological transition Spanish Minister.

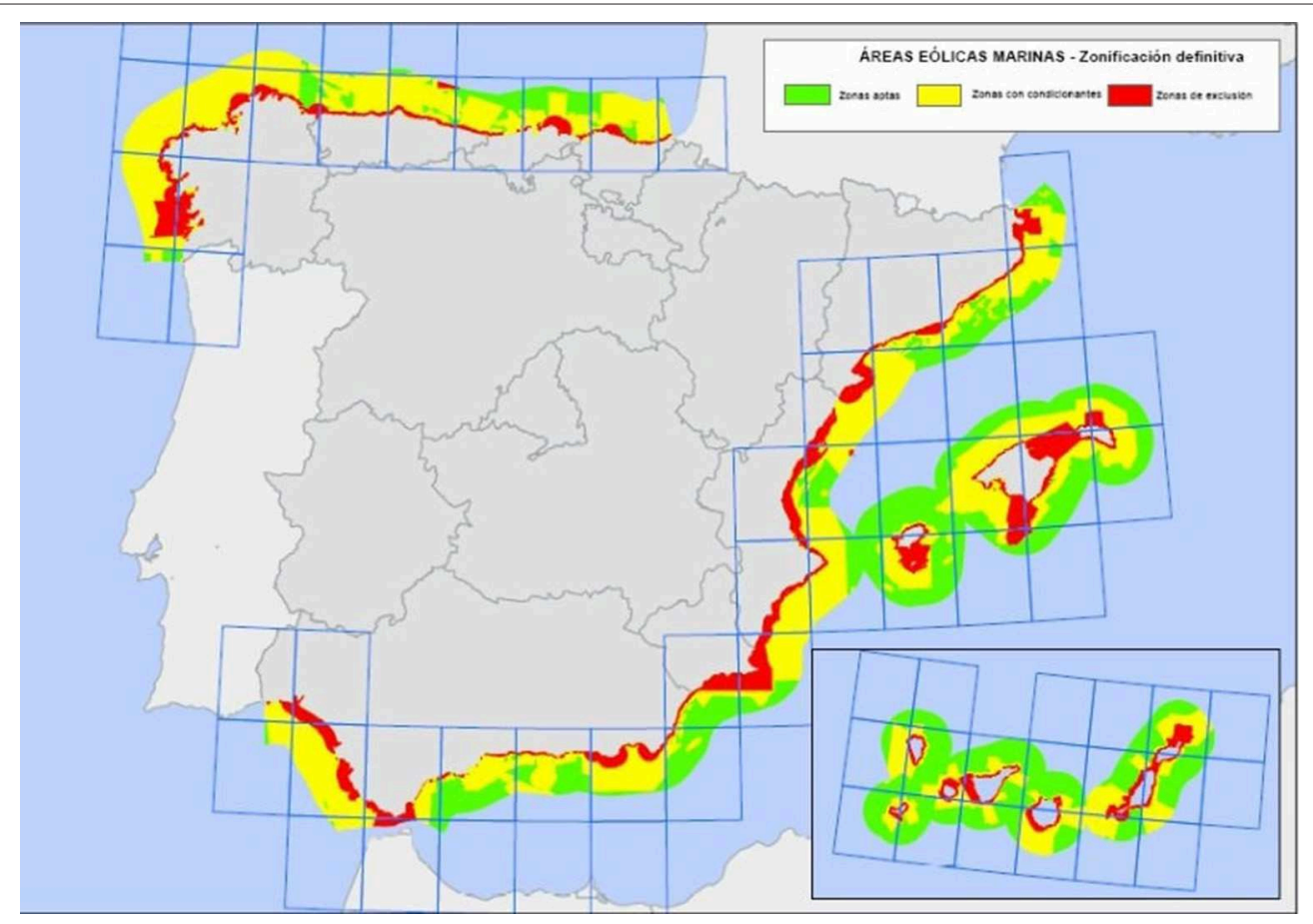

FIGURE 15 | Areas for the installation of offshore projects (green-apt, yellow-apt with conditions, red-excluded). Reproduced from Spanish Ministry (Spanish Ministry of Energy, 2009).

As for the regulations, the Spanish Ministry of Energy determined the areas that are apt for the installation of offshore projects (Figure 15), and the area showed as example is not excluded, but marked as yellow, which means that is apt for the installation of a wind farm but particular considerations must be accounted for. 
In sum, the area of Cadiz would be constituted as a primed location for the installation of offshore wind energy, as the existing technology can be applied without need of modification, the legislation allows this type of project and the conditions (resource, bathymetry and geomorphology) are ideal. This was already found during the project of "Mar de Trafalgar," which was finally rejected due to the lack of social acceptance. In this new scenario, using a gravity based foundation (that would generate a lot of job positions in the area), placing the wind farm in a greater farm-to-coast distance (that would reduce the visual and environmental impact) and engaging all the strata of the society, the success of the project is more likely to be reached.

\section{CONCLUSIONS}

The ambitious objectives of the European Union for reducing $\mathrm{CO}_{2}$ emissions and for increasing renewable energy contribution in the new energy mix, made necessary the contribution of the wide and vast renewable resources of the Mediterranean Sea. The case of the Mediterranean Spanish Arc is the perfect example of the current absence of exploitation of these resources. In the case of offshore wind energy, Spain presents in certain areas one of the largest wind resources of Europe; however, no current projects are foreseen to harness it.

\section{REFERENCES}

Abanades, J., Flor-Blanco, J., Flor, G., and Iglesias, G. (2018a). Dual wave farms for energy production and coastal protection. Ocean Coast. Manag. 160, 18-29. doi: 10.1016/j.ocecoaman.2018.03.038

Abanades, J., Greaves, D., and Iglesias, G. (2014). Coastal defence through wave farms. Coast. Eng. 91, 299-307. doi: 10.1016/j.coastaleng.2014.06.009

Abanades, J., Ivars, J., Molina, R., and García, C. (2018b). "The application of caisson-type solutions to the current offshore wind energy market," in ASME 2018 37th International Conference on Ocean, Offshore and Arctic Engineering (Madrid: American Society of Mechanical Engineers).

Abanades, J., and Torregrosa, J. P. (2018). "MAESTRALE: the implementation of blue energy in the Mediterranean Sea," in ASME 2018 37th International Conference on Ocean, Offshore and Arctic Engineering (Madrid: American Society of Mechanical Engineers).

Arena, F., Barbaro, G., and Romolo, A. (2013). "Installing U-OWC devices along Italian coasts," in ASME 2013 32nd International Conference on Ocean, Offshore and Arctic Engineering (Madrid: American Society of Mechanical Engineers).

Association, E. O. E. (2010). Oceans of Energy European Ocean Energy Roadmap 2010-2050. Charleroi: Imprimerie Bietlot.

Astariz, S., and Iglesias, G. (2015). The economics of wave energy: a review. Renew. Sustain. Energy Rev. 45, 397-408. doi: 10.1016/j.rser.2015.01.061

Astariz, S., Perez-Collazo, C., Abanades, J., and Iglesias, G. (2015b). Co-located wind-wave farm synergies (Operation \& Maintenance): a case study. Energy Convers. Manag. 91, 63-75. doi: 10.1016/j.enconman.2014.11.060

Astariz, S., Perez-Collazo, C., Abanades, J., and Iglesiaset, G. (2015a). Co-located wave-wind farms: economic assessment as a function of layout. Renew. Energy 83, 837-849. doi: 10.1016/j.renene.2015.05.028

Bahaj, A. S. (2011). Generating electricity from the oceans. Renew. Sustain. Energy Rev. 15, 3399-3416. doi: 10.1016/j.rser.2011. 04.032

Bergillos, R. J., López-Ruiz, A., Medina-López, E., Moñino, A., and Ortega-Sánchez, M. (2018). The role of wave energy converter farms on coastal protection in eroding deltas, Guadalfeo, southern Spain. J. Cleaner Prod. 171, 356-367. doi: 10.1016/j.jclepro.2017. 10.018
The present paper describes the potential of Spain for developing this kind of projects through a technology type: gravity based foundations, and more specifically the solution patented by TYPSA: Gravi $\left.{ }^{\circledR}\right)$ and a case study in the Southwest coast of Spain (Cadiz). The paper clearly states the viability to conduct such a project in the Mediterranean Spanish Arc; however, it is also evident that a full agreement between all the strata of the society is necessary to move forward this type of projects.

\section{AUTHOR CONTRIBUTIONS}

The author confirms being the sole contributor of this work and has approved it for publication.

\section{ACKNOWLEDGMENTS}

The author is grateful to the Interreg Med Programme, which has funded the MAESTRALE project (Ref: 1218|1MED15_1.1_M12_116), and to the rest of the partners of the consortium and the project officer for their collaboration and support to conduct this article. For its part, the author on behalf of TYPSA would also like to thank to CEEI their confidence on our work.

Besio, G., Mentaschi, L., and Mazzino, A. (2016). Wave energy resource assessment in the Mediterranean Sea on the basis of a 35-year hindcast. Energy 94, 50-63. doi: 10.1016/j.energy.2015.10.044

Buck, B. H., Ebeling, M. W., and Michler-Cieluch, T. (2010). Mussel cultivation as a co-use in offshore wind farms: potential and economic feasibility. Aquacult. Econ. Manag. 14, 255-281. doi: 10.1080/13657305.2010.526018

De León, S. P., Orfila, A., and Simarro, G. (2016). Wave energy in the Balearic Sea. Evolution from a 29 year spectral wave hindcast. Renew. Energy 85, 1192-1200. doi: 10.1016/j.renene.2015.07.076

Drew, B., Plummer, A. R., and Sahinkaya, M. N. (2009). A review of wave energy converter technology. Proc. Inst. Mech. Eng. Part A J. Power Energy 223, 887-902. doi: 10.1243/09576509JPE782

European Commission (2007). “A European Strategic Energy Technology Plan (SET-Plan)-Towards a low-carbon future," in Communication from the Commission to the Council, the European Parliament, the European Economic and Social Committee and the Committee of the Regions, COM. Available online at: http://eur-lex.europa.eu/LexUriServ/LexUriServ.do?uri= CELEX:52007DC0723:EN:HTML:NOT

EWEA (2012). Delivering Offshore Electricty to the EU. Spatial Planning of Offshore Renewable Energies and Electricity Grid Infrastrutures in an Integrated EU Maritime Policy.

Firestone, J., Kempton, W., Krueger, A., and Loper, C. E. (2004). Regulating offshore wind power and aquaculture: messages from land and sea. J. law Public Policy 14:71.

Higgins, P., and Foley, A. M. (2013). "Review of offshore wind power development in the United Kingdom," in Environment and Electrical Engineering (EEEIC), 2013 12th International Conference on IEEE (Madrid: IEEE).

Jeffrey, H., and Sedgwick, J. (2011). ORECCA European Offshore Renewable Energy Roadmap. Edinburgh: Offshore Renewable Energy Conversion Platform Coordination Action Project.

Lavagnini, A., Sempreviva, A. M., Transerici, C., Accadia, C., Casaioli, M., Mariani, S., et al. (2006). Offshore wind climatology over the Mediterranean basin. Wind Energy 9, 251-266. doi: 10.1002/we.169

Liberti, L., Carillo, A., and Sannino, G. (2013). Wave energy resource assessment in the Mediterranean, the Italian perspective. Renew. Energy 50, 938-949. doi: $10.1016 /$ j.renene.2012.08.023 
Mendoza, E., Silva, R., Zanuttigh, B., Angelelli, E., Andersen, T. L., Martinelli, L., et al. (2014). Beach response to wave energy converter farms acting as coastal defence. Coast. Eng. 87, 97-111. doi: 10.1016/j.coastaleng.2013.10.018

Menendez, M., Camus, P., Mendez, F. J., and Losada, I. J. (2014). Highresolution sea wind hindcasts over the Mediterranean area. Climate Dynam. 42, 1857-1872. doi: 10.1007/s00382-013-1912-8

Moccia, J., Arapogianni, A., Wilkes, J., Kjaer, C., Gruet, R., Azau, S, et al. (2011). Pure Power. Wind Energy Targets for 2020 and 2030.

Puertos del Estado (2008). Guía DE Buenas Prácticas para la Ejecución de Obras Marítimas.

Sahin, B., Bilgili, M., and Akilli, H. (2005). The wind power potential of the eastern Mediterranean region of Turkey. J. Wind Eng. Ind. Aerodynam. 93, 171-183. doi: 10.1016/j.jweia.2004.11.005

Shata, A. S. A., and Hanitsch, R. (2006). Evaluation of wind energy potential and electricity generation on the coast of Mediterranean Sea in Egypt. Renew. Energy 31, 1183-1202. doi: 10.1016/j.renene.2005.06.015

Sierra, J. P., Mösso, C., and González-Marco, D. (2014). Wave energy resource assessment in Menorca (Spain). Renew. Energy 71, 51-60. doi: 10.1016/j.renene.2014.05.017

Spanish Ministry of Energy (2009). Excluded Areas for Offshore Proejcts.

Stoutenburg, E. D., Jenkins, N., and Jacobson, M. Z. (2010). Power output variations of co-located offshore wind turbines and wave energy converters in California. Renew. Energy 35, 2781-2791. doi: 10.1016/j.renene.2010.04.033
Todt, O., González, M. I., and Estévez, B. (2011). Conflict in the Sea of Trafalgar: offshore wind energy and its context. Wind Energy 14, 699-706. doi: $10.1002 /$ we. 446

Vicinanza, D., Contestabile, P., and Ferrante, V. (2013). Wave energy potential in the north-west of Sardinia (Italy). Renew. Energy 50, 506-521. doi: 10.1016/j.renene.2012.07.015

Westerberg, V., Jacobsen, J. B., and Lifran, R. (2013). The case for offshore wind farms, artificial reefs and sustainable tourism in the French Mediterranean. Tourism Manag. 34, 172-183. doi: 10.1016/j.tourman.2012.04.008

Wind Europe (2017). The European Offshore Wind Industry-Key Trends and Statistics 2016.

Zountouridou, E. I., Kiokes, G.C., Chakalis, S., Georgilakis, P.S., Hatziargyriou, N.D. (2015). Offshore floating wind parks in the deep waters of Mediterranean Sea. Renew. Sustain. Energy Rev. 51, 433-448. doi: 10.1016/j.rser.2015.06.027

Conflict of Interest Statement: JA was employed by the company TYPSA.

Copyright $\odot 2019$ Abanades. This is an open-access article distributed under the terms of the Creative Commons Attribution License (CC BY). The use, distribution or reproduction in other forums is permitted, provided the original author $(s)$ and the copyright owner(s) are credited and that the original publication in this journal is cited, in accordance with accepted academic practice. No use, distribution or reproduction is permitted which does not comply with these terms. 